\title{
Engendering Linguistic Variation in Literary Prose via Scientific Discourse
}

\section{Bilimsel Dil Yoluyla Edebi Düzyazıda Dilsel Çeşitlilik Yaratmak}

\author{
(iD) Rahmouna Zidane \\ Tlemcen University, Cezayir \\ mouna_zde@yahoo.com
}

Received: November 4, $2021 \quad$ Accepted: December 27, $2021 \quad$ Published: January 30, 2022

\begin{abstract}
Scientific discourse is characterized by the prevalence of assertive linguistic acts denoting facts devoid of fiction. It is mainly used in scholarly writings to serve scientific, technical or didactic objectives. Nevertheless, it may be found in literary works in their distinct genres including scientific and non-scientific fiction. Consequently, the present article aims at depicting the role and implication of the language of science in literature. It attempts to reveal the authors' manipulation of scientific discourse to denote a sort of linguistic variation within their writings. Various examples were extracted from literary works to illustrate the functional and stylistic variation crafted through the use of the language of science. Discourse analysis was applied to study the functions of scientific language in literary texts. The scrutiny of the mined examples has unveiled that the insertion of scientific discourse in literary prose helps to divulge the characters' register and the writers' stylistic craft.
\end{abstract}

Keywords: Discourse, Science, Literature, Linguistic Acts, Variation

Öz: Bilimsel dil, kurgudan yoksun gerçekleri ifade eden iddialı dilsel eylem/erin yaygınlığı ile karakterize edilir. Esas olarak akademik yazılarda bilimsel, teknik veya didaktik amaçlara hizmet etmek için kullanılır. Bununla birlikte, edebi eserlerde, bilimsel ve bilimsel olmayan kurgu dahil olmak üzere edebi eserlerin farklı türlerinde bulunabilir. Bu nedenle, bu makale bilim dilinin edebiyattaki rolünü ve etkisini tasvir etmeyi amaçlamaktadır. Bununla birlikte, yazarların eserlerinde dilsel varyasyonu belirttiği bilimsel dilin güdümünü ortaya çıkarmaya çalışılmıştır. Bilim dilinin kullanımıyla oluşturulan işlevsel ve üslup çeşittiliğini göstermek için edebi çalışmalardan çeşitti örnekler gösterilmiştir. Bilimsel dilin edebi metinlerdeki işlevlerini incelemek için söylem çözümlemesi uygulanmıştır. Sonuç kısmında, dikkatle incelenen örnekler ile edebi düzyazıya bilimsel dilin dahil edilmesinin edebi yazı karakterlerinin geçmişini ve yazarın üslupbilim becerisini ortaya çıkarmaya yardımcı olduğu görü̈mmüştür.

Anahtar Kelimeler: Söylem, Bilim, Literatür, Dilsel Eylem/er, Varyasyon

\section{Introduction}

Scientific discourse is often alienated to the oral and written expository mode of expression that is mainly employed by scientists or academics. It is a linguistic feature

ORC-ID: R. Zidane 0000-0003-3159-6882 
of non-literary forms of composition and academic writing. However, it may occur in literary texts to denote a stylistic feature deployed by the author and/or reveal the characters' linguistic behaviour when they represent scientists. Accordingly, this article attempts to depict instances of the use of scientific discourse for the purpose of achieving functional and individual variation within literary texts. This issue will be mainly tackled in the forthcoming sections after introducing the main concepts related to the study and explaining the notion of linguistic variation.

In fact, language use reflects the users' performance representing the actual practice of linguistic knowledge. It occurs to achieve various purposes that denote distinct functions. For instance, Hymes (1980) gives importance to the referential and stylistic one. In order to achieve these functions, language use takes two main forms: the utterance and discourse. The utterance level refers to the production of isolated statements whether in speech or writing; it is reflected in the realization of a word, a phrase or a sentence. Hymes (1980) considers the utterance as a linguistic routine embodied in the sequential organization of words. Although the utterance is very often associated with oral communication, it is generally agreed that it may be spoken or written (Huddleston, 1984). The utterance level involves isolated sentences whose functions entail speech acts.

Speech acts are referred to as linguistic acts or language acts (Searle, 1965); they represent micro functions (Wales, 2011 ); they are classified into several categories. The types of speech acts depending on general functions are: representatives, declarations, expressives, commissives and directives (Yule, 1996). Representatives are also called assertives (Searle, 1976). They include assertions, claims, descriptions, statements, hypotheses and suggestions (Finegan, 2008). In written discourse, linguistic acts occur in a restricted perceptual scope between a genuine informative participant represented by the writer and an implicit partner corresponding to the prospective reader (Watts, 1981).

Communication may rely on the employment of isolated utterances but this case is very rare as language use often takes the form of discourse. In fact, discourse is a linguistic entity functioning above the sentence level. The genres of discourse are classified into four categories including behavioural, procedural, narrative and expository discourse; behavioural discourse concerns how persons behave; political speech is an example of such a type; procedural discourse deals with instructions, steps and procedures; it includes how-to-do-books and recipes; Narrative discourse embodies stories and 
accounts; expository discourse pervades in scientific articles and can be recurrent in compositions (Longacre, 1996).

Language use may occur at the level of the utterance or discourse. Furthermore, it may be characterized by the existence of linguistic variation which embodies the alterations occurring in the manner of using language depending on the speaker's or writer's intention and the context of speaking or writing. Accordingly, the present article aims at illustrating some aspects of linguistic variation achieved through the insertion of the language of science in literature. It attempts to unveil the purpose of employing scientific discourse in literature and the main forms of linguistic variation resulting from the use of expository language in literary works.

To achieve this objective, the application of discourse analysis was indispensable to scrutinize a sample of examples extracted from a set of novels; the register characteristics, the type of linguistic acts and style features were studied. Moreover, the assertive linguistic acts implicated in the mentioned passages were cross-checked and substantiated with reference to the scientific studies issued during the era when the cited novels appeared. The exploration of the quoted discourse instances will be divulged within the later sections. Nevertheless, before tackling the practical aspect of the study, it is compulsory to explain the main types of linguistic variation before elucidating the significance of the incorporation of the language of science in literature. Therefore, the following title focuses on the presentation of the features of functional and stylistic variation.

\section{Facets of Linguistic Variation}

Linguistic variation may be observed in the choice of a particular type of discourse, a special kind of jargon or the varying degrees of formality. It may be functional or individual. Functional variation is associated with the linguistic situation; it is reflected in the use of various registers and distinct types of genres (Halliday \& Webster, 2009).

A register implies a type of language employed in a particular context; it is based on the utilization of specific vocabulary referred to as jargon that varies according to the discussed topic, the communication setting or the occupation of the language user. A register corresponds to linguistic variation related to language use; it is influenced by the intentions and the objectives of the participants, the discussed topic and the linguistic context (Romaine, 1994). A register represents a language variety depending on the use of discourse. It may be spoken or written. It is identified on the basis of three 
characteristics including the discourse field that denotes the communicative context and objective, tenor which implies the participants' degree of formality and the discourse mode which may be either written or spoken (Simpson, 2004). It applies peculiar vocabulary and grammatical features that prevail within a certain genre (Johns, 1997).

In fact, a genre is associated with the form and structure of the specific discourse variety; it denotes the category of the communicative events (Swales, 1990). It incorporates a language act (Van Dijk, 1998). Thus, a genre represents a set of linguistic acts (Bazerman, 2004). It is a common communicative system that embodies a register (Swales, 1990). It is an oral or written text that fulfils a specific communicative function through the use of a particular rhetorical mode. The use of a specific genre depends on the choice made by the speakers or writers. This implies that language users display distinct modes of producing discourse referred to as individual variation which means that the linguistic purposes and styles vary from a person to another.

In fact, individual variation is also called stylistic variation (Gimémez-Morino, 1997). It concerns a personal linguistic behaviour encompassing a set of changes and shifts adopted by the speaker or writer while using language. It occurs at the level of styles and idiolects (Ruiz Garrido, 2010). The idiolect denotes a distinct verbal behaviour characterized by a particular style that reflects an individual manner of expression involving linguistic items selected by the language user depending on his/her individual preferences and intentions.

Actually, style is distinct from the idiolect as it depends on a context including a set of language choices that necessitate a sort of awareness from the part of the user (Gimémez-Morino, 1997). It refers to the idiolectal stylistic features that characterize the speech or writing of the individual. However, the notion of style is closely linked to the written form of language; since this concept has been instigated from the term 'stilus' which is a Latin word referring to a tool used for writing, it is employed to denote the writing manner (Verdonk, 2006). It is performed through the personal manipulation of diction and syntax for the purpose of producing a specific effect on the listeners or readers. Variation in style arises depending on the context, the medium and degree of formality; it is intermittently identified as style shifting (Wales, 2011).

The degree of formality of the exploited style varies according to the language user's age, gender and social class as well as the subject and social context. Moreover, stylistic variations are often noticeable at the level of the peculiarity of word choice and syntactic structures (Romaine, 1994). In fact, personal style represents a sign of individual 
variation that reveals the eccentricity of the linguistic behaviour. It is a feature of linguistic performance functioning at the level of the discourse of speakers or writers who may use different kinds of language. One of these forms of discourse is the language of science which characterizes the speech and writing of scientists. Although this linguistic variety represents the communicative mode of scientific prose, it may be found in literary works whose main means of expression is literary language. Consequently, the subsequent title presents an overview of the junction between scientific and literary discourse.

\section{The Language of Science in Literature}

Scientific discourse surpasses the notion of register since it is viewed as a specialized language which has various features that make it distinct from general verbal behaviour although it shares with it some aspects in common (Faber, 2012). It implies the language of science; it is sporadically labelled academic discourse. Nevertheless, these two terms seem to be distinct to a certain extent. The former often denotes the discourse of hard sciences while the latter embodies the language used in various disciplines encompassing both hard and soft sciences (Suomela-Salmi \& Dervin, 2009).

Some scholars view scientific discourse as a particular linguistic register (Lemke, 1990). Scientific writing is expository and impersonal (Hodson, 1998). Indeed, expository discourse is considered as apo-deictic (Bal, 1999); it usually makes use of the present tense (Mc Cabe, 1996). Scientific utterances do not fulfil a performative function as they articulate facts; they are expressed in the passive voice in order to minimize the agent's function in the production of the formulated assertions (Fuchs, 1992).

Scientific discourse relies on nominalization. It can also make use of the active voice with inanimate subjects (Donnelly, 1994). Self-mention may occasionally occur in scientific prose. It represents a major technique for authors to exhibit their own voice embodied in their unequivocal presence in the written discourse via the rate of recurrence of restricted first person pronouns (Herrando-Rodrigo, 2010). The language of science constitutes an important means of expression exploited in daily life; it is often allied to non-fiction prose. Nevertheless, it may be found in literature. This is due to the fact that literary production entails the use of utterances denoting all the kinds of speech acts (Olsen, 1978). Indeed, literature has a performative function (Eagleton, 2008). It depicts a portrait of human experiences delineated through the narrator's account of the characters' conversations and deeds. It represents an artistic way of using language for the purpose of attaining a subjective depiction of perspectives (Sleigh, 2011). 
Actually, literary texts are viewed as virtual or pseudo speech acts (Eagleton, 2008). They constitute fictional representations of people's social and linguistic behaviour. Moreover, they are considered as an emulative sketch of human ideas, conversations and attitudes. This is why they are supposed to incorporate mimetic or quasi-linguistic acts (Carter, 1997). Literature relies on narrative discourse which is characterized by the prevalence of the past tense (Longacre, 1996). It portrays people's interactions through the different modes of communication used in the conversations of the characters depending on their occupation, social background and level of education as well as the context. Thus, it occasionally calls for the exploitation of the language of science in order to depict a genuine form of linguistic expression deployed by scientists personified by specific characters in the fictional narrative.

Indeed, scientific discourse is often used in works of fiction to fulfil specific purposes. It may be included in literary writings whose aim is didactic (Hannay, 1989). It is utilized to inform the readers about scientific issues either through the conversation of characters representing scientists or the language employed by the narrator to refer to science and describe scientific personalities. It may also intrude in literature to document the theories, inventions and scientific debates of the era when the novel was produced. For instance, some Victorian novels furnish a remarkable account of the transformation sciences (Whitworth, 2002).

The language of science can constitute the major means of expression used by writers of science fiction productions to explain the role of scientific discourse in society, to describe technological devices and to formulate technical terms and concepts. It may exist in distinct literary genres whether they are scientific or not. It can contribute to the enrichment of literary language via the inclusion of technical vocabulary and expressions. Moreover, scientific discourse can play an important role in increasing linguistic variation in prose fiction. Consequently, the following section will tackle this aspect using examples extracted from different novels.

\section{The Function of Scientific Discourse within Prose Fiction}

The incorporation of the language of science in literary works can serve different purposes. It may be an ancillary factor that helps to achieve linguistic variation that may be functional and/or stylistic. Scientific discourse is often incorporated in the linguistic variety used by those characters representing scientists, researchers or academics. For example, Jules Verne's Twenty Thousand Leagues under the Seas (1869), which is a science fiction novel, includes instances of scientific discourse embodied in the speech 
of the character, Captain Nemo, who is the commander of the Nautilus, the submarine vessel.

Such a case is illustrated in the following example in which Captain Nemo tells Professor Aronnax about the mysteries of the ocean when he says that "the sea is the be all and the end all. It covers seven-tenths of the planet earth. Its breath is clean and healthy" (Verne, 1869: 41). These statements denote assertive speech acts that designate facts relating to the domain of oceanography. The ideas provided concerning the surface of the ocean stand for a scientific claim. According to Fredol (1865), water covers a little more than the seven tenth or a little less than the three quarters of the global surface of Earth. After mentioning the surface and the purity of the air of the ocean, Captain Nemo moves to the description of its world as he states:

The sea is simply the vehicle for a prodigious, unearthly mode of existence ... and in essence, professor, nature is here made manifest by all three of her kingdoms, mineral, vegetable, and animal. The last of these is amply represented by the four zoophyte groups; three classes of articulates, five classes of mollusks, and three vertebrate classes (Verne, 1869: 41).

The aforementioned passage embodies a set of assertives representing scientific assumptions referring to the classification of the sea creatures made by Cuvier (1817) who claims that the general distribution of the animal kingdom incorporates four large divisions. The previously stated quote denotes a speech-based register taking the form of a fictional conversation. Its field of discourse concerns marine biology. Its mode is a written dialogue. Its tenor highlights a distant relationship between the interlocutors as the character's utterances are formulated in the active voice with inanimate subjects and the academic title, Professor, is employed. In another instance, Nemo uses the terminology of marine navigation to inform Professor Aronnax about navigation appliances as he declares:

these are the devices needed to navigate the Nautilus...the thermometer which gives the temperature inside the Nautilus; the barometer, which measures the heaviness of the outside air and forecasts changes in the weather; the humidistat which indicates the degree of dryness in the atmosphere; the storm glass, whose mixture decomposes to foretell the arrival of tempests; the compass, which steers my course;

Then, he adds:

the sextant, which takes the Sun's altitude and tells me my latitude; chronometers, which allow me to calculate my longitude; and finally, spyglasses for both day and night, 
enabling me to scrutinize every point of the horizon once the Nautilus has risen to the surface of the waves (Verne, 1869: 46).

In the above excerpt, the character is informing his interlocutor about nautical instruments which are listed and explained through definitions. These devices are extensively described by Guépratte (1839) who claims that the instruments of reflection which made a revolution in the art of observing at sea could outfit a travelling and constantly agitated observatory.

In fact, Captain Nemo appears to be like an instructor who is elucidating the meaning of the given concepts and the deployed register seems to fulfil a didactic purpose. The discourse field is related to marine navigation. The mode corresponds to a fictional conversation while the tenor denotes the prevalence of the active voice with inanimate subjects; the first person object pronoun, me, and the possessive pronoun, my, represent self-mentions that are utilized to hint at the significance of the previously mentioned devices for Nemo, who is a sailor.

Scientific discourse is not restricted to the works of science fiction as it may be found in the other types of literary prose. In Two on a Tower (1882), which is a romance novel, Thomas Hardy uses scientific discourse. For example, the character, Swithin, who is a young astronomer, describes the equatorial to Lady Constantine when he says:

It is a splendid instrument, with an object lens of, say, eight or nine inches aperture, mounted with its axis parallel to the earth's axis, and fitted up with graduated circles for denoting right ascensions and declinations; besides having special eye-pieces, a finder, and all sorts of appliances-clock-work to make the telescope follow the motion in right ascension. I cannot tell you half the conveniences. Ah, an equatorial is a thing indeed! (Hardy, 1882: 61).

The aforementioned passage includes the astronomical register; it involves the field of astronomy since the subject turns around the description of an astronomical instrument; the mode is a written dialogue; the tenor entails a formal language characterized by an impersonal style involving the use of the inanimate subject. The first person pronoun which denotes self- mention is employed to convince the interlocutor of the importance of the apparatus as if Swithin is seeking research funding by persuading the funder of the convenience of the instrument. In fact, the quote provides a concise definition of the astronomical mount forming the basis of the portable observatory or the equatorial telescope (Dick, 1855). Furthermore, the astronomical register is exploited in the subsequent example as Swithin proclaims: 
That's because it is so distant that no magnifying will bring its size up to zero. Though called a fixed star, it is like all fixed stars, moving with inconceivable velocity; but no magnifying will show that velocity as anything but rest (Hardy, 1882: 37).

In the above quotation, the field of discourse relates to the domain of stellar kinematics. The mode involves a fictional dialogue. The tenor embodies a formal style characterized by the use of the inanimate agent. The character formulates a set of assertive statements to expose a scientific idea since the huge distance of the closest fixed star whose light moves with the unconceivable velocity of 200,000 miles in every second is extremely tiny and there are more distant stars that cannot be magnified by the most vigorous telescopes (Baillairgé, 1873).

In Hard Times (1854), which is a social-problem novel, Charles Dickens uses the vocabulary of science when the learner, Bitzer, delineates the meaning of a horse as "Quadruped. Graminivorous. Forty teeth, namely twenty-four grinders, four eye-teeth, and twelve incisive. Sheds coat in the spring; in marshy countries, sheds hoofs, too. Hoofs hard, but requiring to be shod with iron. Age known by marks in mouth."(Dickens, 1854: 4). This citation represents an assertive speech act that can be supported by the description supplied by Bewick (1804) who gives many details about the horse and asserts that the age of this animal can be identified via several techniques including the eye-pits and the teeth which represent the optimum criterion of the age of the horse.

The definition provided by Bitzer indicates the use of the register of biology in an educational context. The topic discussed belongs to the field of animal science; the mode of discourse is a written conversation; the tenor denotes an impersonal style categorized by the prevalence of nominalization achieved through the use of verbless sentences employed for the purpose of defining the concept. There is the presence of a compound sentence composed of two subjectless clauses utilized in order to provide extra explanations; the ellipted subject refers to the horse but it is omitted to achieve brevity taking into account that the meaning is implied by reader.

The previously mentioned passages exemplify the role of the language of science in producing functional variation in literary works through the exhibition of distinct technical registers utilized by the characters depending on their occupation and the fictional context of language use. Moreover, scientific discourse is implicated in prose fiction to contribute to the generation of stylistic variation. Indeed, the language of science can be incorporated in literary texts for mere stylistic purposes. For instance, in Jules Verne's Eighty Days around the World (1873) which is an adventure novel, the writer 
displays scientific facts to provide clarifications; before presenting evidence, he mentions a set of explanations when he says:

How was it that a man so exact and fastidious could have made this error of a day? How came he to think that he had arrived in London on Saturday, the twenty-first day of December, when it was really Friday, the twentieth, the seventy-ninth day only from his departure? The cause of the error is very simple. Phileas Fogg had, without suspecting it, gained one day on his journey, and this merely because he had travelled constantly eastward; he would, on the contrary have lost a day had he gone in the opposite direction, that is, westward (Verne, 1873: 312).

In the aforementioned passage, Verne shifts in tense use moving from the past perfect when mentioning the date of Fogg's arrival to the past tense when referring to the real date. Subsequently, he employs the historic present tense to ascertain the evidence of the reason behind the faulty calculation of the number of days of the trip. Then, the past perfect is utilized to recount the character's gaining of a day. After that, he states:

In journeying eastward he had gone towards the sun, and the days therefore diminished for him as many times four minutes as he crossed degrees in this direction. There are three hundred and sixty degrees on the circumference of the earth; and these three hundred and sixty degrees, multiplied by four minutes, give precisely twenty-four hours - that is, the day unconsciously gained. In other words, while Phileas Fogg going eastward, saw the sun pass the meridian eighty times, his friends in London only saw it pass the meridian seventy-nine times (Verne, 1873: 312).

In the above excerpt, the author produces a narrative act relying on the use of the past tense. Then, he generates assertive linguistic acts expressed in the present tense to fulfil an informative purpose. The information provided to justify the cause of Phileas Fogg's early arrival is not fictitious; it is a factual detail that is tied to the fact the Sun spends 24 hours to cross 360 degrees and takes four minutes to travel one degree in its diurnal movement; multiplying the number of degrees intercepted between the two meridians by four results in the number of minutes expressing the difference in the completed hours in the two proposed places at the same time; this explains why the voyagers who travel around the earth gain or lose a day when returning to their countries; a traveller journeying from the West to the East of the Earth gains 24 hours while a voyager travelling from the East to the West counts 24 hours less (Chalret, 1787).

This scientific claim that has been stated by Verne in the aforementioned passage not only helps to convey a general truth but it also elicits the resolution events to attain the 
denouement. After that, the writer switches to narration utilizing the past tense to bring the reader back to the story. In this way, the narrator shifts from narrative to scientific discourse to achieve stylistic variation and to insinuate that literary texts are not devoid of factual verbal behaviour even if they embrace a great deal of fictional discourse. Another example of the exploitation of the language of science for stylistic aims can be illustrated in the subsequent example. In George Eliot's Middlemarch (1872), which is a historical novel, a scientific claim is entailed in the following excerpt:

your pier-glass or extensive surface of polished steel made to be rubbed by a housemaid, will be minutely and multitudinously scratched in all directions; but place now against it a lighted candle as a centre of illumination, and lo! The scratches will seem to arrange themselves in a fine series of concentric circles round that little sun. It is demonstrable that the scratches are going everywhere impartially and it is only your candle which produces the flattering illusion of a concentric arrangement, its light falling with an exclusive optical selection... The scratches are events, and the candle is the egoism of any person now absent- of Miss Vincy for example. Rosamond had a providence of her own (Eliot, 1872: 255).

In the aforementioned passage, the author hints at the denotation of the character's moral trait by generating a similitude resulting from the deployment of a scientific claim. She varies the types of discourse in the same passage. She uses the procedural mode of writing formulated through the future tense and generic reference denoted by the impersonal pronoun, your, referring to the imprecise agent implying any reader as well as the directive linguistic act performed via the imperative tense. Then, she switches to the expository mode using a representative speech act expressed in the present tense and introduced by an inanimate agent.

This assertive statement represents an illusion to the candle light mirroring that can be substantiated by a statement explaining light reflection and refraction provided by Huygens (1690) who claims that the production of light that each small spot of a luminous body, like the Sun, a candle or a burning coal, engenders rays whose location is the centre; for instance, concentric circles represent the rays which come from the flame of a candle; the double refraction of the rays of light can be discerned when observing the candle flame through the crystal cut into prisms.

After formulating the scientific statement concerning the reflection of light, Eliot makes use of the historic present expressed in the metaphors relating to events and egoism to highlight the vividness of the stated ideas. Then, she shifts to the narrative mode 
involving the past tense to pursue the description of the character and bring back the reader to the course of the story. In this way, the narrator alters the kinds of discourse using distinct linguistic acts to denote intra-author stylistic variation.

In another instance, Eliot introduces scientific vocabulary in Middlemarch when she states:

...living bodies, fundamentally considered, are not associations of organs ... but must be regarded as consisting of certain primary webs or tissues, out of which the various organs - brain, heart, lungs and so on - are compacted... Bichat with his detailed study of the different tissues, acted necessarily on medical function ... here would be another light as of oxy-hydrogen showing the very grain of things and revising all former explanations. Of this sequence to Bichat's work, already vibrating along many currents of the European mind, Lydgate was enamoured; he longed to demonstrate the more intimate relations of living structure (Eliot, 1872: 143-144).

In the above excerpt, the narrator formulates assertive statements presented in the present tense; she refers to the ideas of Bichat (1801) who claims that the different parts of the cellular system perform the role of a bond that connects the body organs and an intermediate anatomy that separates them; extended inside these organs, the cellular system basically contributes to their structure. After delineating Bichat's theory concerning the cellular tissue, Eliot switches to the past tense to chronicle the deeds of the mentioned scientist. Then, she shifts to the use of the past perfect tense to connote the significance of the microscope; in this way, the narrator sheds light on one of the inventions of the nineteenth century referring to the oxy-hydrogen microscope which relies on the lime-ball light (Brewster, 1837); this instrument which is also called the oxy-hydrogen engiscope is based on the light generated through yielding lime to the action of the oxy-hydrogen blowpipe (Goring \& Pritchard, 1837). After eliciting the achievements made in the domain of medical research, the narrator resumes the narration of the story by explaining Lydgate's interest and perspectives in medical investigations using the past tense.

The language of science is exploited by various novelists. For example, in Tess of the D'Ubervilles (1891), which is considered as a pastoral novel, Thomas Hardy uses scientific discourse for the description of a natural phenomenon when he says:

The grey half-tones of daybreak are not the grey half-tones of the days' close, though the degree of their shade may be the same. In the twilight of the morning, light seems active, darkness passive; in the twilight of evening it is the darkness which is active and crescent, and the light which is the drowsy reverse. Being so often -possibly not always 
by chance- the first two persons to get up at the dairy-house, they seemed to themselves the first persons up of all the world. (Hardy, 1891: 166-167).

In the aforementioned excerpt, the narrator describes the twilight using a set of assertive statements; the present tense is employed to denote a real phenomenon. This portrayal discloses a scientific claim referring to the fact that the Sun illuminates the atmospheric strata which throw back some of the received light to engender twilight which is halftone of light produced before sunrise and after sunset; the twilight is feeble or powerful depending on the degree of the Sun's dispersion below the horizon; it is stronger in the evening than in the morning since after sunset, the distribution of the rays of the Sun is supported by vapour whose quantity in the lower layers of the atmosphere is greater after dusk (Chambers, 1891).

The picture of the twilight is stated to refer to the liveliness of the characters, Tess and Clare; it entails the importance of getting up early to achieve the untimely tasks of skimming and milking as well as Tess's vivacity which makes her distinct from the others. The portrayal of this natural phenomenon suggests the significance of being awaken at a premature time and the opportunity of discerning the differences between daylight and nightfall. After exploring a real fact by depicting the features of the twilight as a natural phenomenon, the writer shifts to the past tense to talk about the awakening of the characters and carry on the process of narration. Therefore, the previously mentioned examples give an idea about the contribution of the language of science to the enrichment of functional and stylistic variation in literary prose. The summary of the main results and further discussion will be displayed in the next section.

\section{Discussion}

The language of science is a form of verbal behaviour used for academic, scientific and didactic purposes. It denotes facts and reality, it is often utilized in non-fiction speech or writing. The occurrence of the scientific discourse in literature may be sometimes imposed by the genre of the literary work as it is usually deployed in science fiction prose to portray the perspectives of science and refer to technical innovations. Generally speaking, it can be exploited in any type of literary text to produce a specific effect.

The analysis of the extracted passages has revealed that the use of scientific discourse in novels can serve to fulfil a referential function as the previously mentioned characters formulate scientific statements to supply the interlocutors with information about technical concepts such as a nautical device, an astronomical instrument, a celestial body or a living creature. Furthermore, the narrator may use technical vocabulary to perform 
a realistic sketch of the scientific persons and findings shaping a historical period involved in the story. In addition to this, it can be claimed that scientific discourse can become a potent stylistic device; this can be inferred from the examples illustrating Verne's exploitation of the language of science to achieve the resolution of the narrative and Eliot's deployment of scientific vocabulary for generating an analogy.

Moreover, the analysed excerpts have denoted the fact that scientific discourse can play an important role in generating linguistic variation in literary prose; it can highlight functional variation when denoting distinct technical registers involved in the conversations of the characters representing scientists. Indeed, these characters employ daily register in their different conversations in addition to the scientific jargon used in specific communicative contexts. They personify persons belonging to distinct scientific disciplines; their technical registers vary depending on their occupations; for instance, in Twenty Thousand Leagues under the Seas, the nautical jargon pervades in the speech of Captain Nemo since he is a sailor; in Two on a Tower, the astronomical register is recurrent in the verbal behaviour of Swithin who is interested in astronomy; in Hard Times, the learner, Bitzer, employs scientific vocabulary to answer the question given in an educational context.

In addition to its embodiment in the characters' register, the language of science can contribute to the generation of stylistic variation when combined with literary language; in this case, it can be revealed through the authors' style shift that helps to display distinct modes of composition and expose the writers' skill in writing. It can lead to intra-author variation due to the stylistic alteration produced by the same writer within the same novel or distinct literary works. The inclusion of scientific discourse in literature can also represent a major aspect of inter-author variation since the degree of using scientific discourse in literary prose may vary from a writer to another. It depends on the literary genre and the nature of the personalities depicted by the characters as well as the writer's intentions, cultural background and degree of interest in science.

The scientific discourse encompassed in literary texts can help the reader to get supplementary knowledge about science and scientists; it can even push the audience's curiosity to make further research in order to know more about the scientific theories and inventions cited in the novels. Additionally, it can constitute a resource for instructors teaching language for specific purposes as it may be exploited to introduce the students to the jargon of scientific disciplines; it can also be used by language teachers to illustrate the features of the expository mode of discourse. The utilization of the language of science in literature can enable linguists to provide new insights about 
the alliance of the different forms of linguistic behaviour and their role in boosting linguistic variation.

\section{Conclusion}

Scientific discourse denotes the language of science that is mainly used in academic contexts for informative and expository purposes. As it is a form of daily language, it can occur in literary prose to depict instances of real-life communicative events expressed through assertive linguistic acts performed by the characters or the narrator. It can be an indicator of the registers and styles of scientists and academics embodied in literary texts. Thus, it can function as a device serving to engender functional and stylistic variation.

The interplay between literary and scientific language results in a type of prose fiction that mingles pleasure with instruction. This implies that literary discourse is but a manifestation of the different forms of language used by people in everyday life exhibited in an artistic way. The study of the exploitation of scientific discourse in literature can disclose various perspectives concerning the contribution of literary prose to the exposition of the language and achievements of science. Therefore, further research is needed to unveil the importance of literary and scientific discourse as well as the assortment of different modes of expression in literary texts.

\section{References}

Baillairgé, C. (1873). Geometry, mensuration and the stereometrical tableau. Quebec: C. Darveau.

Bal, M. (1999). Introduction. In M. Bal (Ed.), The Practice of Cultural Analysis: Exposing Interdisciplinary Interpretation. (pp. 1-14). Stanford: Stanford University Press.

Bazerman, C. (2004). Speech acts, genres and activity systems: How texts organize activity and people. In C. Bazerman, P. Prior (Ed.), What Writing Does and How It Does It: An Introduction to Analyzing Texts and Textual Practices (pp. 309-340). New Jersey: Lawrence Erlbaum Associates, Inc.

Bewick, T. (1 804). A general history of quadrupeds. New York: G\& R Waite.

Bichat, X. (1801). Anatomie générale, appliquée à la physiologie et la médicine. Paris: Brosson, Gabon et Cie.

Brewster, D. (1837). A treatise on the microscope. Edinburgh: Adam \& Charles Black.

Carter, R. (1997). Investigating English discourse: Language, literacy and literature. UK: Routledge.

Chalret, M.J. (1787). Elémens d'arithmétique, de géométrie et d'algèbre. Montauban: Vincent Teulières

Chambers, G. F. (1891). Pictorial astronomy for general readers. London: Whitaker \& Co. 
Cuvier, G. (1817.). Le règne animale. Paris: Deterville.

Dick, Thomas. (1855). The practical astronomer. New York \& London: Harper \& Brothers Publishers.

Dickens, C. (1854). Hard times. London: The Penguin Group.

Donnelly, C. (1994). Linguistics for writers. USA: State University of New York Press

Eagleton, T. (2008). Literary theory: An introduction. USA: University of Minnesota Press.

Eliot, G. (1872). Middlemarch. London: The Penguin Group.

Faber, P. (2012). Introduction. In P. Faber (Ed), A Cognitive Linguistics View of Technology and Specialized Language (pp. 1-6). Berlin: Walter de Gruyter.

Finegan, E. (2008). Language: Its structure and use. USA: Thomson Wordsworth.

Fredol, A. (1865). Le monde de la mer. Paris: Hachette.

Fuchs, S. (1992). The professional quest for truth: a social theory of science and knowledge. USA: State University of New York Press.

Gimémez-Morino, R. (1997). The boundaries of the concepts of genre, register and style in academic discourse. In J. Pigné, A.J. Viera (Ed.) Applied Linguistics: Theory and Practice in ESP (pp. 37-44). Valencia: Universitat de Valencia.

Goring, C.R. ve Pritchard. A. (1837). Micrographia. London: Whittaker \& Co.

Guépratte, C. (1839). Problèmes d'astronomie nautique et de navigation. Brest: Lefournier.

Halliday, M.A.K. and Webster, J. (2009). Continuum companion to systematic functional linguistics. London. Continuum International Publishing Group.

Hannay, J. (1989). The literary uses of the rhetoric of science: USA: Georgia State University.

Hardy, T. (1882). Tow on a tower. New York and London: Harper \& Brothers Publishers.

Hardy, T. (1891). Tess of the D'Ubervilles. London: The Penguin Group.

Herrando-Rodrigo, I. (2010). "If you suffer from.. check the internet": the role of engagement and self-mention devices in medical research articles and electronic popularizations. In R.Lorés-Sanz, P. Mur-Dueňas, E. Lafuenta-Millán (Ed.), Constructing Interpersonality: Multiple Perspectives on Written Academic Genres (pp. 255-274). UK: Cambridge Scholars Publishing. Hodson, D. (1998). Teaching and Learning Science: Towards a Personalized Approach. UK: Open University Press.

Huddleston, R. (1984). Introduction to the grammar of English. Cambridge: CUP.

Huygen, C. (1690). Traité de la lumière. Leiden: Pierre Vander.

Hymes, D. (1980). Language in education: Ethnographic essays. USA: Center for Applied Linguistics.

Johns, A. M. (1997). Text, role and context: Developing academic literacies. Cambridge: CUP.

Lemke, J. L. (1990). Technical discourse and technocratic ideology. In M.A.K Halliday; J. Gibbons, H. Nicholas (Ed.), Learning, Keeping and Using Language (pp. 435-460), Amsterdam/

Philadelphia: John Benjamin's Publishing Company.

Longacre, R. E. (1996). The Grammar of discourse. New York: Plenum Press.

Mc Cabe, A. (1996). Evaluating narrative discourse skills. In K. N. Cole, P.S. Dale, D. J. Thai (Ed.), Assessment of Communication and Language. (pp. 121-142). Baltimore: Paul H. Brockes Publishing Co, Inc.

Olsen, S. H. (1978). The structure of literary understanding. Cambridge: CUP. 
Romaine, S. (1994). Language in society. Oxford: OUP.

Ruiz Garrido, M.F. (2010). Language variation in English for business and economics. In R. Gimémez-Morino (Ed.), Words for Working: Professional and Academic English for International Business and Economics (pp. 57-95). Valencia: PUV.

Searle, J. (1965). What is a speech act? In M. Black (Ed.). Philosophy in America (pp. 221-239). London: Allen \& Unwin.

Searle, J. (1976). A Classification of illocutionary acts. Language in Society. 5(1).1-23.

Simpson, P. (2004). Stylistics: A resource book for students. London: Routledge.

Sleigh, C. (2011). Literature and science. UK: Palgrave McMillan.

Suomela-Salmi, E. and Dervin, F. (2009). Introduction. In E. Suomela-Selmi, F. Dervin (Ed.), Cross-Linguistic and Cross-Cultural Perspective on Academic Discourse (pp.1-18). Amsterdam/Philadelphia: John Benjamins Publishing Company.

Swales, J. M. (1990). Genre analysis: English in academic and research setting. Cambridge: CUP. Van Dijk, T. A. (1998). Ideology: A multidisciplinary approach. London: Sage Publication Ltd.

Verdonk, P. (2006). Style. In K. Brown (Ed.) Encyclopaedia of Language and Linguistics (pp. 196210). Oxford: Elsevier.

Verne, J. (1873). Eighty Days around the World. (Geo M. Towle, Trans.). Philadelphia: Porter \& Coates. (Original work published 1873).

Verne, J. (2016). Twenty thousand leagues under the seas. (F.P.Walter, Trans.) Canada: Woodstock. (Original work published 1869).

Wales, K. (2011). A dictionary of stylistics. USA: Taylor \& Francis Group.

Watts, R. (1981). The pragmalinguistic analysis of narrative texts: Narrative cooperation in Charles Dickens's hard times. Tübingen: Gunter Narr Verlag.

Whitworth, M. H. (2002). Science and scientists in Victorian fiction. In W. Baker, K. Womack (Ed.) A Companion to Victorian Novel (pp. 111-121). USA: Greenwood Press. 